\title{
THE STUDY REGARDING CORRUPTION CARRIED OUT BY THE WORLD BANK
}

\author{
W. G. Brînză
}

\section{William Gabriel Brînză}

Faculty of Law, Law Department

"Dimitrie Cantemir" Christian University, Bucharest, Romania

*Correspondence: William Gabriel Brînză, "Dimitrie Cantemir" Christian University, 176 Splaiul Unirii, 4th District, Bucharest, Romania

E-mail:william@williameuropa.eu

\begin{abstract}
For a long period of time, corruption was accepted as being an inevitable fact of life. Corruption in the $27 \mathrm{EU}$ member states undermines citizens' fundamental rights, good governance and the rule of law. In 2000, the World Bank carried out a study about corruption at the request of the Romanian Government. The elaboration process and the implementation of an anticorruption strategy depend on the state's politics and priorities.
\end{abstract}

Keywords: corruption, World Bank, worldwide, the impact

\section{Introduction}

\section{Corruption - a worldwide affair}

For a long period of time, corruption was accepted as being an inevitable fact of life. Recently, despite the fact that there wasn't any opinion which considers corruption a major threat in the way to evolution, a factor which affects the constitutional state, the democracy or the economic perspectives of the society, there has been a dramatic change of attitude worldwide. This thing can be explained by an adjunction of extremely different factors, which allowed corruption to install in the top problems of mankind.

The United States of America, after the follow-up the scandals Watergate and Lockheed, adopted a legislation intended for the prevention on "illicit payments in the international transactions". The American's wish to elaborate a convention project in the U.N. failed in 1979, no state from the Eastern or Western Europe wasn't ready for such an approach against the corruption phenomenon'.

Starting with the '80s, once the attention towards economic crime organized by the penal politics grew, and once the internal scandals of corruption burst, industrial countries all over the world made the first steps in taking an attitude against this phenomenon.

Relatively recently, a lot of scandals hit different parts of the world. Thus, in Asia, after the fall of the Indonesian president Suharto, his family was attacked several times, existing the proof that the state was prejudiced by the former administration, which declined the implementation of reforms and has extorted billions from the national wealth.

In Pakistan, the prime minister, Benazier Bhutto, and in India, the prime minister, P.V. Maraschima Kao, were both expunged from the government due to corruption incriminations. In South Korea, the former presidents Rah Tae Woo and Chan Doo Hwan were both incarcerated being accused of taking bribe from certain Korean companies. In Japan, a great number of leaders of the government and important businessmen were the targets of the corruption scandals and accusations.

\footnotetext{
${ }^{1}$ V. Dobrinoiu, p. 48.
} 
In Latin America, area which is presently struggling with important economic problems, which generate street fights, the accusations of bribery climax with the treachery of the presidents Fernando Collor de Mello of Brazil and Carlos Andrés Perez of Venezuela. The most serious case registered between 2001 and 2002 took place in Argentina, where local corruption joined hands with the international corruption to prejudice the national economy, bringing the people in a state of despair.

In Mexico, the president Carlos Salinas de Gortari was investigated for the enormous sums of money gathered illicit by his brothers. The president Ernesto Tamper of Columbia was accused of accepting money from the Cali drug cartel, fact which had a negative impact on the Columbian poll, which didn't support him in the presidential elections.

The failure of the Spanish prime minister, Felipe Gonzales was due to the corruption scandals inside his cabinet. Also, the president of Zaire, Mobatu Sese Seko, was expelled from the administration because of the people's resentment towards the fact that he took million dollars bribery.

Corruption is a phenomenon spread worldwide, which contracts gigantic dimensions, starting to strike the most important areas of the economic, politic and social life. It is like a disease which spreads rapidly, and for which the antidote hasn't yet been found.

The international commerce registered last year a multiplication of acts of corruption. In this domain, occult commissions extended alarmingly mostly in the countries in transition to the market economy. Experience has demonstrated that the corruption acts are practiced not only on a national scale, but on a continental and global scale as well, proving that the phenomenon knows no frontiers. More analysts came to the conclusion that "the global process of corruption is faster than the globalization of the economy, and, in more than one case, the globalization of some economic sectors implicated serious acts of corruption. Obviously there are countries in which the level of corruption and the frequency of corruption acts are smaller, and some countries where these have alarming dimensions. The interest in obtaining illicit funds has no ethnic or geographic color, and it doesn't characterize a certain country. Corrupters and corrupt people exist in all the countries, that is why a firm action to combat this phenomenon is needed, because corruption dangerously spread in the last decade. $^{2}$ An alarming development took the fraud in commercial exchange. Corrupt elements improved their action techniques on the degree of commercial exchange.

They put together techniques and strategies meant to defraud "national fortunes of some nations", bringing them, most of the times, in a state of breakdown. The knowledge of the types and forms of the corruption acts represents an obligation of all the national and international factors involved in the fight against this disaster of the XXI century. ${ }^{3}$

In 2000, the World Bank carried out a study about corruption at the request of the Romanian Government. In this study, an important part was played by the means of reducing and combat corruption.

The elaboration process and the implementation of an anticorruption strategy depend on the state's politics and priorities. There are states in which the reforms had quick results, mainly because of the applied programs, which decomposed the problem of corruption and tried to solve it piece by piece. Such a strategy should contain:

a) Transparency and responsibility in the politic life.

To accomplish this condition it is necessary the existence of clear rules about the conflict of interests, the declaration of the dignitaries' fortunes, the financing of political

\footnotetext{
${ }^{2}$ Dumitru Mazilu, "Preventing and relucting corruption" - major undiscriminating of the development of commercial trades based on the fundamental principles and specifications of the international commerce", The Commercial Law no. 1/ 2002, page 108.

${ }^{3}$ Samuel P. Huntington, "Political Order in Changing Societes", Yale University Press, New Haven and London, 1968 , page 62.
} 
parties. It is true that these laws do not guarantee the implication of politicians in corrupt businesses, but they can discourage these facts, once there is a higher probability that a corrupt politician can be exposed. This direction is also following the separation of political and economical interests, issue solved by promoting the principle of transparent financing of the political parties and of the electoral campaigns. Thus, there are brought into light the connections between the politicians and the interests that they promote or not. There are states in which the principle of transparency through a very rigid manner: thus, the politicians are forbidden to use the means of the state (funds, cars), in order to earn the confidence of the public opinion and to assure the electorate that the authorities provide for the interests of the society before their personal ones.

b) The improvement of the public administration.

In this direction a few reforms must be enforced, reforms about budgetary management concerning the politic alloy in the responsibilities of the public servants, promoting meritocracy, to appoint some behavior rules for the clerks who must build a pattern concerning their normal behavior.

c) The existence of a solid business environment which can be ease the implementation of a less burdensome legislation for those who want to invest in different domains, to eliminate bureaucracy, which is a permanent source of corruption, to reduce legal obligations which are hard to acquit by different enterprises.

d) Lastly, in order to apply an anticorruption program it is necessary to open towards the society, which presuppose free access of the public and the civil society organizations to any information about the activities of the state's administration. In many states, the freedom of information was enacted, which managed to attract the civil society and the media and to transform them into true allies against corruption. It is important to earn the society's confidence in the Government's actions, but this thing will not happen until a coherent, credible anticorruption strategy will be implied, which ought to be followed by notable progresses in the implementation and supervising.

The attenuation of corruption implies not only strong compulsion, but also the development of the administration of the public sector and social changes. In Slovakia and Lithuania the strategies were based on three key elements:

To punish corruption according to the law;

- $\quad$ To educate the people about the rights they have when they come in contact with the public sector; administration.

The combat of corruption through the development of the public sector's

In adopting decisions to combat corruption, must participate, governmental organizations and representatives outside the government (like different non-governmental organizations) which can have as an effect the growing confidence in the measures which were taken.

\section{Concluding thoughts}

Corruption in the $27 \mathrm{EU}$ member states undermines citizens' fundamental rights, good governance and the rule of law. Corruption occurs in old and new EU Member States alike. Research shows that the trust of EU citizens in Member States and the EU to fight corruption is very low.

\section{Solution:}

The EU must do more to counteract corruption with a comprehensive anti-corruption policy. The prevention of and fight against corruption should remain a priority on the EU's political agenda. Leaders and decision-makers at the EU- and Member State level must take a clear and public stance against corruption, while adequate EU legislation, mechanisms and standards against corruption are needed to tackle the issue at its roots. 
The Bank — as is the case with many others working in this area — is at an early stage of building up a body of knowledge on what works and does not work in the fight against corruption. We have much to learn on the design and implementation of effective anticorruption strategies. The elements sketched out in this brief paper attempt to illustrate a broad and evolving framework, not a blueprint. This framework needs to be filled in with research, country studies, lessons and best practices drawn from country experiences, open dialogue with governments and civil society, and strong interaction and partnerships with other donors and agencies participating in these efforts.

Tackling corruption is neither easy nor quick. The causes are complex and the means to control it are not fully understood. There are no single magical solutions and, as with most problems in development, it must be attacked on many fronts simultaneously.

An anti-corruption strategy must also go beyond first principles, such as adopt marketfriendly policies, reduce red tape or provide training, helpful though these actions may be.

Leadership is a key. The sustained reduction of systemic corruption requires committed leadership and support from civil society. Constructive pressure and assistance from abroad can help, but cannot substitute if the political will is missing.

The role of civil society is another key. Where executive political will exists, the role of civil society may be akin to being partners with government in the implementation and monitoring of anti-corruption programs. Where such political will is absent or tepid, civil society's role has a different dimension - it needs to foster the willingness of the political leadership to reform.

\section{Bibliography}

Dumitru Mazilu, "Preventing and relucting corruption" - major undiscriminating of the development of commercial trades based on the fundamental principles and specifications of the international commerce", The Commercial Law no. 1/ 2002;

A Report of the George C. Marshall European Center of Security Studies Conference on Corruption Within Security Forces - A Threat to National Security, May 14-18, 2001, Garmish-Parten Kirchen, Germany;

Samuel P. Huntington, "Political Order in Changing Societes", Yale University Press, New Haven and London, 1968. 